\title{
TISSUE TOLERANCE AND DRUG TRANSPORT STUDIES OF DMSO APPLIED TO THE GONADS OF BULLS AND BOARS
}

\author{
W. LEIDL AND W. BIERGERT \\ Department of Andrology and Artificial Insemination, \\ Ambulatory Animal Hospital and Hospital for Animal Gynecology, \\ University of Munich
}

(Received 18th September 1967)

\begin{abstract}
Summary. The cutaneous absorption of penicillin dissolved in DMSO and penicillin dissolved in water were compared following topical application to the testis of two boars and two bulls. DMSO demonstrated pharmacodynamic activities, which suggests that further study of its activity by topical application in the therapy of epididymal and testicular diseases is indicated.
\end{abstract}

The treatment of epididymal and testicular diseases due to inflammation or trauma with antibiotics, sulphonamides and corticosteroids, administered parenterally, provides only limited chances for therapeutic success. The introduction of DMSO (dimethyl sulphoxide) and its analgesic, antiphlogistic and bacteriostatic properties offered a possible means for the development of local therapy for these diseases. When applied topically DMSO actively penetrates cell membranes and it is capable of carrying or transporting certain drugs through the skin. The toxicity, penetration and transport of DMSO, either alone or combined with penicillin or flumethasone, $6 \alpha 9 \alpha$-difluoro-16 $\alpha$ methylprednisolone, were studied following topical application to the gonads of normal bulls and boars, in an attempt to establish the possible clinical usefulness of such an approach.

The tolerance or toxicity of the drug was judged by its effect on sperm formation and maturation in five bulls (A to $\mathrm{E}$ ). Pure DMSO was used in two bulls (A and B), DMSO-penicillin in two others ( $\mathrm{C}$ and $\mathrm{D}$ ) and DMSOflumethasone in one $(\mathrm{E})$.

Semen samples (single ejaculates) from the bulls were obtained twice weekly for 8 weeks before and 8 to 12 weeks after treatment and checked routinely by the usual criteria (ejaculate volume; sperm morphology; sperm movement).

The treatments with DMSO demonstrated good local penetration of the drug. The administration of $96 \%$ DMSO resulted in erythema of the scrotum, which disappeared after about $30 \mathrm{~min}$. There was no influence on spermatogenesis at the dose and the duration of time used for these applications. The amount of ejaculate, the sperm concentration, the percentage of spermatozoa moving forward and the proportion of primary malformed spermatozoa was 
TABLE 1

AGE AND WEIGHT OF THE ANIMALS EMPLOYED AND DOSES AND DURATION OF APPLICATION OF THE DRUGS INVOLVED

\begin{tabular}{|c|c|c|c|c|c|}
\hline Animal & $\begin{array}{l}\text { Body weight } \\
(\mathrm{kg})\end{array}$ & $\underset{(\text { years })}{\text { Age }}$ & Vehicle & $\begin{array}{c}\text { Treatment } \\
\text { dosage and drug }\end{array}$ & $\begin{array}{c}\text { No. of } \\
\text { applications } \\
\text { 24-hr intervals }\end{array}$ \\
\hline $\begin{array}{l}\text { Experimental } \\
\text { Bull A } \\
\text { Bull B } \\
\text { Bull C } \\
\text { Bull D } \\
\text { Bull E } \\
\text { Bull F } \\
\text { Bull G } \\
\text { Boar H } \\
\text { Boar J }\end{array}$ & $\begin{array}{l}675 \\
500 \\
450 \\
450 \\
500 \\
675 \\
500 \\
180 \\
175\end{array}$ & $\begin{array}{l}3 \\
2 \\
2 \\
2 \\
1 \cdot 5 \\
3 \\
2 \\
2 \\
2\end{array}$ & $\begin{array}{l}10 \mathrm{ml} \text { DMSO } \\
10 \mathrm{ml} \text { DMSO } \\
10 \mathrm{ml} \text { DMSO } \\
10 \mathrm{ml} \text { DMSO } \\
10 \mathrm{ml} \text { DMSO } \\
10 \mathrm{ml} \text { DMSO } \\
10 \mathrm{ml} \text { DMSO } \\
10 \mathrm{ml} \text { DMSO } \\
10 \mathrm{ml} \text { DMSO }\end{array}$ & $\begin{array}{l}- \\
2 \times 10^{6} \text { i.u. penicillin } \\
2 \times 10^{6} \text { i.u. penicillin } \\
2.5 \mathrm{mg} \text { flumethasone } \\
20 \times 10^{6} \text { i.u. penicillin } \\
20 \times 10^{6} \text { i.u. penicillin } \\
2 \times 10^{6} \text { i.u. penicillin } \\
6 \times 10^{6} \text { i.u. penicillin }\end{array}$ & $\begin{array}{l}1 \\
2 \\
3 \\
3 \\
3 \\
3 \\
1 \\
1 \\
1 \\
1\end{array}$ \\
\hline $\begin{array}{l}\text { Control } \\
\text { Bull K }\end{array}$ & 500 & 2 & $10 \mathrm{ml}$ distilled & & \\
\hline Bull L & 550 & 2 & $10 \mathrm{ml}$ distilled & $20 \times 10^{\circ}$ s.u. penicillin & \\
\hline Bull $\mathrm{M}$ & 500 & 2 & $\begin{array}{r}\text { water } \\
-\end{array}$ & U & - \\
\hline
\end{tabular}

not changed 8 to 12 weeks after treatment as compared to controls (see Table 2). A temporary increase in the proportion of secondary malformed spermatozoa following application of DMSO was noted between the 4th and 6th posttreatment day, but in two bulls this was not observed until the beginning of the 3rd post-treatment week (Bulls A and B; Table 3). Penicillin and flumethasone did not show any additional influence on sperm production or maturation.

The activity of DMSO as a means for drug resorption was tested in two boars $(\mathrm{H}$ and $\mathrm{J})$ and in two bulls $(\mathrm{F}$ and $\mathrm{G})$ by using penicillin as a test substance. For control purposes the scrota of two bulls ( $\mathrm{K}$ and $\mathrm{L}$ ) were painted with

TABLE 2

EJAGULATE GOMPOSITION OF THE BULLS A, B, C, D, AND E BEFORE AND AFTER TREATMENT WITH DMSO (AVERAGE VALUES OF FOUR EJAGULATES/2 WEEKS/BULL)

\begin{tabular}{|c|c|c|c|c|c|c|}
\hline \multirow{2}{*}{$\begin{array}{c}\text { Treatment } \\
\text { (weeks) }\end{array}$} & \multirow{2}{*}{$\begin{array}{l}\text { No. of } \\
\text { ejaculates }\end{array}$} & \multirow{2}{*}{$\begin{array}{c}\text { Ejaculate } \\
\text { volume } \\
(m l)\end{array}$} & \multirow{2}{*}{$\begin{array}{c}\text { Density } \\
\left(10^{6} / \mathrm{mm}^{3}\right)\end{array}$} & \multirow{2}{*}{$\begin{array}{c}\text { Progression } \\
(\%)\end{array}$} & \multicolumn{2}{|c|}{$\begin{array}{l}\text { Pathologic malformed } \\
\text { spermatozoa }\end{array}$} \\
\hline & & & & & Primary & Secondary \\
\hline $\begin{array}{l}\text { Before } \\
8 \text { to } 7 \\
6 \text { to } 5 \\
4 \text { to } 3 \\
2 \text { to } 1\end{array}$ & $\begin{array}{l}16 \\
16 \\
16 \\
20\end{array}$ & $\begin{array}{l}3 \cdot 6 \\
4 \cdot 0 \\
3 \cdot 4 \\
3 \cdot 6\end{array}$ & $\begin{array}{l}0.78 \\
0.95 \\
1.00 \\
0.92\end{array}$ & $\begin{array}{l}72 \\
67 \\
69 \\
59\end{array}$ & $\begin{array}{l}3 \cdot 8 \\
4 \cdot 3 \\
2 \cdot 8 \\
2 \cdot 7\end{array}$ & $\begin{array}{r}10.7 \\
11.3 \\
9.9 \\
10.8\end{array}$ \\
\hline $\begin{array}{l}\text { After } \\
1 \text { to } 2 \\
3 \text { to } 4 \\
5 \text { to } 6 \\
7 \text { to } 8 \\
9 \text { to } 10 \\
11 \text { to } 12\end{array}$ & $\begin{array}{l}20 \\
20 \\
20 \\
20 \\
12 \\
12\end{array}$ & $\begin{array}{l}3 \cdot 6 \\
3 \cdot 1 \\
3 \cdot 9 \\
3 \cdot 1 \\
2 \cdot 9 \\
3 \cdot 3\end{array}$ & $\begin{array}{l}0.96 \\
1.09 \\
1.03 \\
0.97 \\
0.70 \\
0.68\end{array}$ & $\begin{array}{l}64 \\
62 \\
64 \\
63 \\
55 \\
48\end{array}$ & $\begin{array}{l}3 \cdot 8 \\
3 \cdot 0 \\
3 \cdot 1 \\
2 \cdot 6 \\
2 \cdot 8 \\
2 \cdot 4\end{array}$ & $\begin{array}{r}15 \cdot 1 \\
11 \cdot 6 \\
8 \cdot 0 \\
6 \cdot 0 \\
7 \cdot 3 \\
4 \cdot 6\end{array}$ \\
\hline
\end{tabular}


TABLE 3

PERCENTAGE OF SECONDARY MALFORMED SPERM IN EJACULATE FORM BEFORE AND AFTER TREATMENT WITH DMSO (AVERAGE VALUES OF FOUR EJAGULATES/2 WEEKS/BULL)

\begin{tabular}{|c|c|c|c|}
\hline Treatment (weeks) & Bulls $A$ and $B$ & Bulls $C$ and $D$ & Bull $E$ \\
\hline $\begin{array}{l}\text { Before } \\
8 \text { to } 7 \\
6 \text { to } 5 \\
4 \text { to } 3 \\
2 \text { to } 1\end{array}$ & $\begin{array}{l}7 \cdot 0 \\
8 \cdot 2 \\
8 \cdot 2 \\
8 \cdot 2\end{array}$ & $\begin{array}{l}14.9 \\
14 \cdot 3 \\
11.5 \\
13.9\end{array}$ & $\begin{array}{l}\text { N.E.* } \\
\text { N.E. } \\
\text { N.E. } \\
10 \cdot 0\end{array}$ \\
\hline $\begin{array}{l}\text { After } \\
1 \text { to } 2 \\
3 \text { to } 4 \\
5 \text { to } 6 \\
7 \text { to } 8 \\
9 \text { to } 10 \\
11 \text { to } 12\end{array}$ & $\begin{array}{r}8 \cdot 4 \\
14 \cdot 0 \\
8 \cdot 9 \\
7 \cdot 1 \\
\text { N.E. } \\
\text { N.E. }\end{array}$ & $\begin{array}{r}21 \cdot 6 \\
11 \cdot 2 \\
8 \cdot 1 \\
5 \cdot 6 \\
7 \cdot 0 \\
4.4\end{array}$ & $\begin{array}{r}15 \cdot 2 \\
7 \cdot 7 \\
5 \cdot 8 \\
4 \cdot 3 \\
4 \cdot 6 \\
6 \cdot 8\end{array}$ \\
\hline
\end{tabular}

* N.E., Not examined.

a penicillin solution in distilled water and one bull (M) received no treatment (Table 1). The tissue samples were taken from different parts of the testis, epididymis and the various tissue layers around the testis (see Table 4). In the boars, sampling was done $3 \mathrm{hr}$ and in the bulls $4 \mathrm{hr}$ after treatment. Penicillin was demonstrated by employing the Difco-Antibiotic-Agar diffusion test with B. subtilis ATCC 6633 as the test germ and the use of a penicillin standard from Bayer.

Antibiotic concentrations were observed mainly in the tissue layers around the testis and in all organs covered with serosa. The resorption by the serosa and the denseness of the tunica albuginea and the stratum vasculosum as a barrier greatly inhibited the penetration of penicillin into the testis parenchyma. In the bull, a species with a testis which could be treated from all sides, an antibiotic level of 4.2 i.u./ $/ \mathrm{ml}$ was shown in the marginal layers of the testis

TABLE 4

AVERAGE OF PENIGILLIN GONGENTRATION IN THE DIFFERENT PARTS OF THE TESTIS, THE EPIDIDYMIDES, THE TISSUES SURROUNDING THE TESTIS IN FOUR BULLS AND TWO BOARS (AVERAGE VALUES OF FOUR SAMPLES) (PENIGILlin PENETRATED AS GIVEN IN i.u. $/ \mathrm{g} / \mathrm{ml}$, RESPECTIVELY)

\begin{tabular}{l|c|c|c|c}
\hline \multicolumn{1}{c|}{ Experimental animal } & Bull $M$ & Bulls $K$ and $L$ & Bulls $F$ and $G$ & Boars $H$ and $\mathcal{F}$ \\
\hline Vehicle & - & Water & DMSO & DMSO \\
Organ: & & & & \\
Testicle parenchyma & 0 & 0 & $4 \cdot 2$ & 0 \\
$\quad$ Edge & 0 & 0 & 0.8 & 0 \\
$\quad$ Centre & 0 & Trace & $2 \cdot 4$ & $0 \cdot 7$ \\
Epididymis & 0 & $1 \cdot 8$ & $9 \cdot 0$ & $3 \cdot 0$ \\
$\quad$ Head & 0 & $60 \cdot 0$ & $200 \cdot 0$ & N.E.* \\
$\quad$ Tail & 0 & $5 \cdot 0$ & $200 \cdot 0$ & N.E. \\
Tunica vaginalis communis & 0 & 0 & $0 \cdot 7$ & N.E. \\
Tunica albuginea & & & \\
\hline
\end{tabular}

* N.E., Not examined. 
parenchyma, while in the centre of the parenchyma the level $0.8 \mathrm{i} . u . / \mathrm{ml}$ was only insignificantly higher than the blood level of $0.7 \mathrm{i} . \mathrm{u} . / \mathrm{ml}$. The high concentration in the epididymides is probably due to the serosa which covers that organ. In the boars, penicillin could only be demonstrated in the epididymides (head: 0.7 i.u./g; tail: 3.0 i.u./g).

Flumethasone and DMSO were donated by the Syntex Research Institute of Veterinary Science, Mexico, D.F. 